\title{
Succession of hydrocarbon seep communities associated with the long-lived foundation species Lamellibrachia luymesi
}

\author{
Erik E. Cordes ${ }^{1,3, *}$, Stephane Hourdez ${ }^{2}$, Benjamin L. Predmore ${ }^{1}$, \\ Meredith L. Redding ${ }^{1}$, Charles R. Fisher ${ }^{1}$ \\ ${ }^{1}$ Biology Department, Pennsylvania State University, 208 Mueller Lab, University Park, Pennsylvania 16802, USA \\ ${ }^{2}$ Equipe Ecophysiologie, CNRS-UPMC UMR 7127, Station Biologique, BP74, 29682 Roscoff, France \\ ${ }^{3}$ Present address: Department of Organismal and Evolutionary Biology, Harvard University, 26 Oxford St., Cambridge, \\ Massachusetts 02138, USA
}

\begin{abstract}
The vestimentiferan tubeworm Lamellibrachia luymesi lives for over 250 yr and forms aggregations of hundreds to thousands of individuals at hydrocarbon seep sites in the Gulf of Mexico. A succession model has been proposed where changes in the abiotic environment within tubeworm aggregations lead to shifts in the associated community structure. Here, we test this model using new data from communities associated with 13 tubeworm aggregations. We quantify the temporal scale of succession by using a population-growth model to estimate aggregation age. In older tubeworm aggregations, biomass, density, and number of species $\mathrm{m}^{-2}$ tube surface area decline. In addition, primary producer, primary consumer, and endemic species comprise a smaller proportion of the tubeworm-associated community in old aggregations. These changes in the associated community are attributed to lower epibenthic sulfide concentrations in older aggregations. A number of species' densities show strong correlations to sulfide concentration, and similarity between communities is best explained by a combination of aggregation age and sulfide concentration. Together, these data demonstrate the role of hydrogen sulfide in this seep habitat and the effect that the hypothesized reduction of epibenthic sulfide concentration by L. luymesi would have on the associated community.
\end{abstract}

KEY WORDS: Community ecology $\cdot$ Succession $\cdot$ Facilitation $\cdot$ Biogenic habitat $\cdot$ Foundation species $\cdot$ Deep sea $\cdot$ Hydrocarbon seep · Vestimentiferan $\cdot$ Hydrogen sulfide

\section{INTRODUCTION}

Positive species interactions allow the species involved to colonize and persist in previously exclusionary habitats, expanding their ecological niches (Higashi 1993, Bruno et al. 2003). While the effects of these interactions on the species directly involved have been demonstrated, the ecological impact of these relationships on the surrounding community is less well understood (Stachowicz 2001). The creation of physical structure by foundation species (Bruno et al. 2003) can be the most significant force affecting community structure on the landscape scale (Hacker \&
Gaines 1997). The positive species interactions implicit in the creation of biogenic habitat can lead to elevated diversity as compared to the surrounding, unaltered habitat (Hacker \& Gaines 1997). Tropical rain forests and coral reefs harbor some of the most diverse communities known in terrestrial and marine systems (Connell 1978). This type of positive interaction has repercussions well beyond the species directly involved, affecting entire communities of organisms (Bertness \& Leonard 1997).

Modification of the abiotic environment can further alter the community structure of biogenic habitats. As habitat conditions change over time, persistence of 
some species is inhibited, while colonization by other species is facilitated (Harris et al. 1984). This transitional period can be followed by a stable state persisting on long temporal scales. Ponds created by beavers exist for decades (Naiman et al. 1986), forests may persist for centuries, while coral reef structures endure for millennia. If the effects of habitat modification are manifested in a predictable and consistent sequence, these are considered successional processes (Odum 1969).

Communities associated with biogenic habitats at hydrocarbon seeps on the continental slope of the Gulf of Mexico have been proposed to follow such a successional sequence (Bergquist et al. 2003a). On the upper Louisiana slope these communities are usually dominated in terms of biomass by vestimentiferan tubeworms with internal chemoautotrophic sulfide-oxidizing (thiotrophic) symbionts and/or bathymodiolin mussels with internal methanotrophic symbionts (Brooks et al. 1987, MacDonald et al. 1990). These foundation species create habitats that support a high-biomass assemblage of endemic species along with numerous non-endemic species exhibiting elevated abundance relative to the surrounding seafloor (Carney 1994).

The model of succession proposed by Bergquist et al. (2003a) involves a sequence of 4 community stages. These communities begin with mussel (Bathymodiolus childressi) beds containing high biomass communities of low diversity and high endemicity. In this first stage, relatively high levels of methane and sulfide result in high microbial productivity, but also produce an exclusionary environment favoring endemic species with presumably high sulfide and hypoxic tolerances (Bergquist et al. 2003b, 2005). The next 3 successional stages consist of vestimentiferan tubeworm aggregations dominated by Lamellibrachia luymesi along with Seepiophila jonesi. The mussel bed stage overlaps with and is succeeded by the second stage, 'juvenile' tubeworm aggregations (Bergquist et al. 2003a). Abundant hydrogen sulfide (Bergquist et al. 2003b) and ongoing authigenic carbonate precipitation (Formolo et al. 2004) as a byproduct of high sulfate reduction rates (Aharon \& Fu 2000, Joye et al. 2004) result in active tubeworm recruitment during this period (Bergquist et al. 2002, Cordes et al. 2003). The similarity of communities occupying the habitat created by different foundation species, mussel beds and young tubeworm aggregations, may be a result of the levels of sulfide and, to a lesser extent, methane in the environments of both habitats (Bergquist et al. 2003a, 2005). The third stage involves a reduction in sulfide concentrations in the epibenthos (Freytag et al. 2001, Bergquist et al. 2003b), leading to increased colonization by non-endemic species with presumably lower tolerances to sulfide and hydrocarbons (Carney 1994, Bergquist et al. 2003a). The mixture of endemic and non-endemic species results in higher overall diversity, but lessened local productivity leads to lower total biomass of fauna (Bergquist et al. 2003a). In older aggregations, epibenthic sulfide levels continue to decline, leading to further reductions in biomass of tubeworm-associated fauna, most notably endemic primary-consumer species (Bergquist et al. 2003a). This final stage may last for centuries, as $L$. luymesi individuals often live for over $250 \mathrm{yr}$ (Fisher et al. 1997, Bergquist et al. 2000).

Temporal changes in sulfide concentration may result in part from the alteration of the environment by Lamellibrachia luymesi. This tubeworm species can obtain sulfide through posterior extensions of its body, known as 'roots' (Julian et al. 1999, Freytag et al. 2001). High uptake rates, exceeding $30 \mathrm{mmol} \mathrm{h}^{-1}$ in moderate sized aggregations (Cordes et al. 2003), will serve to deplete sulfide as it is carried upward by seeping fluids. Their roots may also physically impede or divert seepage by growing down through existing seepage conduits (Bergquist et al. 2003a). Theoretical studies suggest that L. luymesi further affects sulfide flux by releasing sulfate into deeper sediment layers (Cordes et al. 2005). If suitable electron donors are available, sulfate will be reduced to sulfide in deeper sediment layers. By shifting the site of sulfate reduction, gaseous and liquid hydrocarbons seeping upward with pore fluids will be depleted at greater sediment depths. In addition, enhanced authigenic carbonate precipitation, a byproduct of anaerobic methane oxidation and hydrocarbon degradation (Boetius et al. 2000, Formolo et al. 2004), would impede advection (Luff et al. 2004). Increasing population and individual size in older aggregations will increase the effect of tubeworm tubes on current regime and particle deposition rates, leading to deeper sediment layers around the aggregation base (MacDonald et al. 1990), potentially contributing to the decline in epibenthic sulfide concentration. Together, these modifications of the tubeworm-generated habitat would facilitate colonization by non-endemic species.

In this study, we examine the 'testable model of seep vestimentiferan community development' proposed by Bergquist et al. (2003a). The majority of the information that formed the basis of the model was gleaned from 4 quantitative and 3 qualitative collections using the visual appearance of aggregations to place them in a general temporal sequence. Here, we test this model in a mensurative experiment using 13 new quantitative samples of tubeworm communities, including 3 collections from a site that had not been previously sampled. Specifically, we test the hypotheses that overall density and biomass of heterotrophic fauna, abundance of primary consumers, and numbers of endemic species decline over time. A population growth model is used to objectively estimate the age of each aggregation 
from the size frequency of Lamellibrachia luymesi in that aggregation. Community data are further examined with respect to temporal trends in sulfide concentration, as inferred from the chronosequence of the aggregations. We also correlate the distribution of the more common species with aggregation age and sulfide concentration to examine species-specific distribution patterns. Together, these data are used to test several of the hypotheses posed by Bergquist et al. (2003a) in order to provide a comprehensive description of the factors governing succession at Gulf of Mexico hydrocarbon seeps.

\section{MATERIALS AND METHODS}

A total of 13 vestimentiferan aggregations were collected on 3 cruises aboard the RV Seward Johnson II in 2002, 2003, and 2004. Collections were made at 2 sites on the upper Louisiana slope of the Gulf of Mexico. The sites were approximately $10 \mathrm{~km}$ apart in the Green Canyon (GC) 234 (Site 1, 27 $44.7^{\prime} \mathrm{N}, 9^{\circ} 13.3^{\prime} \mathrm{W}$ ) and 232 (Site $2,27^{\circ} 44.5^{\prime} \mathrm{N}, 91^{\circ} 19.1^{\prime} \mathrm{W}$ ) lease blocks of the upper Louisiana slope and ranged from 528 to $571 \mathrm{~m}$ deep. These sites appear to have similar geophysical and geochemical settings (Sager et al. 2003), including similar hydrocarbon gas composition (Sassen et al. 1994) and hydrogen sulfide concentrations (Aharon \& Fu 2000, 2003), as well as the presence of methane hydrate breaching the seafloor (C. Fisher pers. obs.).

For determination of the tubeworm-associated community structure, vestimentiferan aggregations were obtained using the Johnson Sea-Link I and II submersibles with the Bushmaster Jr. and Bushmaster Sr. collection devices. The Bushmaster collection devices are hydraulically actuated nets lined with a $63 \mu \mathrm{m}$ mesh. Bushmaster Jr. has an open diameter of $70 \mathrm{~cm}$, and Bushmaster Sr. has an open diameter of $150 \mathrm{~cm}$. Tubeworm aggregations were collected by placing one of the devices over the aggregation and constricting a stainless-steel cable around the base. The aggregation was removed from the sediment and the intact collection placed in a receptacle mounted to the front of the submersible. For Bushmaster Jr. collections, the receptacle was the bottom half of a 30 gallon drum lined with $63 \mu \mathrm{m}$ mesh. In Bushmaster Sr. collections, the device was placed on a $1.8 \mathrm{~m}$ diameter trampoline mounted to the front of the submersible. Once the submersible was retrieved, the Bushmaster was removed from the receptacle and the aggregation placed into a plastic tub on the deck of the ship. All contents of the Bushmaster and the receptacle were washed into the tub. At this point, associated fauna were separated and the tubeworms removed from the tub. The contents of the tub were sieved through a $2 \mathrm{~mm}$ mesh, and retained organisms were sorted onboard to the low- est possible taxonomic level. Subsamples of smaller-size fractions were retained for future small macrofaunal and meiofaunal community investigations.

All associated fauna were preserved and transported back to Pennsylvania State University for final determination of taxonomic status. E. E. Cordes and S. Hourdez identified all polychaetes. Primary identification of other groups was carried out using existing voucher collections at Pennsylvania State University, with specimens of other taxa sent to experts for further identification or verification as needed. All individuals were weighed and enumerated for subsequent analyses. Preserved wet weight was converted to ash free dry weight (AFDW) using existing species-specific conversion factors (Bergquist et al. 2003a) when available, or by published higher taxonomic level conversion factors (Ricciardi \& Bourget 1998). Species were assigned a trophic level based on published species-specific trophic relationships based on stable isotope data (MacAvoy et al. 2002, 2005) or feeding structure morphology (Waren \& Bouchet 2001) when possible, or reported family- or higher-level trophic interactions (Fauchald \& Jumars 1979, Waren \& Bouchet 2001, Bergquist et al. 2003a and references therein). Primary producers were defined as species with thiotrophic or methanotrophic symbionts. Primary consumers are grazing, suspension-feeding, or filter-feeding species. Secondary consumers were predatory fauna, and higher-order consumers were larger predatory or scavenging fauna. Species are reported as endemic if they have only been collected at cold seeps or contain thiotrophic or methanotrophic symbionts. Community diversity of each collection was assessed using the Shannon-Weaver diversity index $\left(H^{\prime}\right)$ :

$$
H^{\prime}=-\sum_{i=1}^{\mathrm{n}} p_{i} \ln \left(p_{i}\right)
$$

where $p_{i}$ is the relative abundance (\%) of the ith species. Community evenness was determined using Pielou's index of evenness $\left(J^{\prime}\right)$ :

$$
J^{\prime}=\frac{H^{\prime}}{\ln S}
$$

where $S$ is the total number of species in all collections. Encrusting species for which individuals were very difficult to enumerate were marked as present or absent. These included sponges, colonial cnidarians, and a species of sabellid polychaete commonly found on the tubes of Lamellibrachia luymesi and Seepiophila jonesi. Because the individuals of these taxa were not enumerated they could not be included in quantitative analyses of community similarity or diversity but were included in species-richness analyses.

Tubeworms were counted and measured onboard, time permitting. Remaining tubeworms were preserved in formalin and transported back to Pennsylva- 
nia State University for processing. Length was measured to a standardized posterior outer tube diameter; $2 \mathrm{~mm}$ for Lamellibrachia luymesi and $4 \mathrm{~mm}$ for Seepiophila jonesi (Bergquist et al. 2000, Cordes et al. 2005). These diameters were the common points where the tubeworms entered a dense, tangled mass at the base of the aggregations. Surface area was calculated as for a cone frustrum:

$$
S A=\frac{1}{3} \pi \times l\left(A D^{2}+P D^{2}+A D \times P D\right)
$$

where $S A=$ surface area, $l=$ length,$A D=$ anterior diameter, and $P D=$ posterior diameter. Published conversions of length to AFDW were used to calculate biomass of tubeworm species (Bergquist et al. 2003a).

Aggregations were assigned an age using a population growth model (Cordes et al. 2003). The model includes population-size dependent recruitment, individual size-specific growth, and individual sizespecific mortality for Lamellibrachia luymesi. Seepiophila jonesi was not included in the model due to a paucity of data on their growth and mortality rates. The model was run with aggregation-specific recruitment parameters derived from cohort analysis of sizefrequency distributions. If the non-linear recruitment function could not converge on a set of parameter estimates for a given aggregation, then pooled estimates of recruitment parameters were used. The model was run until the average length of tubeworms in the simulation was within $1 \mathrm{~cm}$ of the actual average length. At the end of each model run, the frequency of tubeworms in $10 \mathrm{~cm}$ size classes was compared to the actual size-frequency distribution of the collected aggregation using a log-likelihood test. This method has been shown to provide consistent estimates among model runs and qualitatively, if not quantitatively, reproduce sampled size-frequency distributions (Cordes et al. 2003). The 100 best-fitting simulations of the 1000 iterations of the model were selected for each aggregation and average age determined from this subset of model realizations.

To estimate the exposure of tubeworm-associated communities to hydrogen sulfide, discrete water samples were taken at different heights within an aggregation and analyzed. Water samples were taken at 3 heights in association with each aggregation: near the sediment-water interface at the base of an aggregation (sediment height), approx. halfway between the sediment and the top of the aggregation (mid-level), and near the tubeworm plumes at the top of the aggregation (plume height). Because the aggregations varied in height, mid-level and plume-height samples varied in absolute distance from the sediment surface. Water samples were obtained through a continuous length of $0.5 \mathrm{~mm}$ internal diameter PEEK tubing run- ning from a wand that could be grasped by the manipulator arm of the submersible, through a penetrator, to a valve inside the rear chamber of the submersible and terminating with a LeurLock connector to which the collection syringe could be attached (Nix et al. 1995). The dead volume of the system is $1.5 \mathrm{ml}$, and $2.0 \mathrm{ml}$ was flushed between samples.

Hydrogen sulfide concentration was measured using the enzymatic assay of Singh et al. (1993) as modified by Freytag et al. (2001). This assay measures the concentration of all sulfide species, though at bottom-water $\mathrm{pH}$ (7.7, Aharon \& Fu 2000) the majority (86\%) of total sulfide is in the form of $\mathrm{HS}^{-}$. Within the submersible, samples were collected in $1 \mathrm{ml}$ gas-tight syringes containing $150 \mu \mathrm{l}$ of a $3.4 \mathrm{mM}$ enzyme (papain) and $20 \mathrm{mM}$ sodium acetate solution. The papain enzyme is activated in the presence of sulfide and forms a complex to prevent further oxidation of sulfide within the syringe. The syringe is kept on ice until retrieval of the submersible when the papain solution is added to a $3.55 \mathrm{mM} \mathrm{L}$-Bapna solution in EDTA buffer. The activated form of papain cleaves the L-Bapna molecule, releasing a p-nitroaniline chromophore that can be quantified using a colorimetric assay on a spectrophotometer. In our experiments, standard curves were run for the 0.2 to $2.0 \mu \mathrm{M}$ sulfide concentration range concomitantly with each set of samples. All sample values under $0.2 \mu \mathrm{M}$ were not significantly different from 0 (confidence interval of predicted value overlapped 0) and were therefore treated as 0 in the analysis. Although standard curves were run to a maximum concentration of only $2 \mu \mathrm{M}$ for each set of samples in order to assure accurate determination at low concentrations, values slightly above this range (2 out of 73 ) were reported based on the empirically determined linear relationship of concentration and absorbance up to at least $5 \mu \mathrm{M}$. Samples were not available for 3 of the 13 collections due to either clogging of the small diameter tubing by sediment or other methodological problems. Regression of log-transformed aggregation age and sulfide concentration was used to assess temporal trends in habitat chemistry.

Similarity in community structure between aggregations was examined by multidimensional scaling (MDS) analysis using PRIMER software (PRIMER-E). This analysis is an iterative procedure that minimizes the difference between ranked Bray-Curtis (BC) similarity values and 2-dimensional distance between each pair of samples. Prior to determination of the pairwise Bray-Curtis similarity, species abundance was standardized to tubeworm surface area to provide a measure of species density irrespective of collection size. Density data were 4 th root transformed to reduce the bias toward the most dominant species (Clarke \& Warwick 2001). The Bray-Curtis similarity was determined using the following function: 


$$
S j k=100\left[1-\frac{\sum_{i=1}^{p}\left|y_{i j}-y_{i k}\right|}{\sum_{i=1}^{p}\left(y_{i j}+y_{i k}\right)}\right]
$$

where Sjk is the Bray-Curtis similarity between the jth and $k$ th samples, $y_{i j}$ is the abundance of the ith species in the $j$ th sample $y_{i k}$ is the abundance of the $i$ th species in the $k$ th sample, and $p$ is the total number of species. The MDS plot is a 2-dimensional representation of the Bray-Curtis similarity between a sample and all of the other samples in the study. This is a non-metric procedure; therefore the axes of the 2-dimensional plot (see Fig. 2) do not have units and the absolute distance between 2 samples qualitatively but not quantitatively represents their similarity.

To assess the relative influence of abiotic factors on community similarity, a modified BIO-ENV procedure (Clarke \& Warwick 2001) was used. Similarity (Euclidean distance) between collections was determined for each environmental factor. Spearman rank correlation between the Bray-Curtis similarity in community structure and the Euclidean distance in habitat characteristics was used to determine the environmental factor that best explained the pattern in community similarity. Variables tested included aggregation age, sulfide concentration, distance between samples (pairwise Euclidean distance between latitude and longitude), and water depth. Age was log-transformed $(\log (x+1))$ to account for the skewed distribution of ages sampled. Sulfide concentration was also log-transformed and entered into the model as average concentration of plume-, mid-, sediment-level, and all samples, as well as proportion of samples with detectable $(>0.2 \mu \mathrm{M})$ sulfide concentrations. Average sulfide concentrations were used to account for the unequal sample size at various heights within different aggregations. The paucity of additional, relevant abiotic data precluded the use of canonical correlation, and principal components analysis (not shown) did not provide the level of resolution between collections achieved in the MDS analysis.

Similarity between species distributions was assessed using a cluster analysis of Bray-Curtis similarity values for the 25 most common species. Commonality was determined by the average of each species' rank in density, biomass, and frequency of occurrence in the collections. The 25 species selected in this manner included at least 7 of the 10 most abundant species in each collection and the 10 most abundant species in 5 of the collections. Cluster analysis was based on group average linkage of the Bray-Curtis similarity in species densities with bootstrap confidence values from 1000 iterations. Relative density (\% individuals of each species in each collection) data were used to investigate changes in the pattern of distribution unbiased by the magnitude of abundance in a given collection. Correlations between the abundance of the 25 most common species and aggregation age and sulfide concentration were determined by Spearman rank correlation. A sequential Bonferroni correction for confidence level $(\alpha / n$ where $\alpha=0.05$ and $n=$ number of comparisons) was used to account for the potentially confounding effects of multiple comparisons (Sokal \& Rohlf 1995).

Table 1. Characteristics of collected tubeworm aggregations arranged by rank age. Numbers under 'Aggregation name' refer to Site 1 (GC234) and Site 2 (GC232), letters (a-j) assigned in order of collection and superscripts refer to collection device ${ }^{\mathrm{a}}=$ Bushmaster Jr., ${ }^{b}=$ Bushmaster Sr.). Abundance of Lamellibrachia luymesi and Seepiophila jonesi, average age as estimated by the population growth model, diversity estimated by Shannon-Weaver diversity index $\left(H^{\prime}\right)$ and Pielou's index of evenness $\left(J^{\prime}\right)$ are also shown

\begin{tabular}{|c|c|c|c|c|c|c|c|c|c|c|}
\hline $\begin{array}{l}\text { Aggregation } \\
\text { name }\end{array}$ & $\begin{array}{c}\text { Water } \\
\text { depth } \\
(\mathrm{m})\end{array}$ & $\begin{array}{l}\text { Abund } \\
\text { L. luymesi }\end{array}$ & $\begin{array}{l}\text { lance } \\
\text { S. jonesi }\end{array}$ & $\begin{array}{l}\text { Average } \\
\text { length } \\
(\mathrm{cm} \pm \mathrm{SD})\end{array}$ & $\begin{array}{l}\text { Average } \\
\text { age } \\
(\mathrm{yr} \pm \mathrm{SD})\end{array}$ & $\begin{array}{c}\text { Tube surface } \\
\text { area } \\
\left(\mathrm{m}^{2}\right)\end{array}$ & $\begin{array}{c}\text { No. of } \\
\text { species }\end{array}$ & 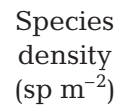 & $H^{\prime}$ & $J^{\prime}$ \\
\hline $1 h^{a}$ & 528 & 601 & 117 & $12.5 \pm 18.7$ & $8.0 \pm 0.2$ & 0.338 & 23 & 68 & 1.60 & 0.542 \\
\hline $1 g^{a}$ & 539 & 92 & 29 & $14.6 \pm 18.6$ & $8.2 \pm 0.4$ & 0.060 & 14 & 233 & 1.60 & 0.623 \\
\hline $2 a^{b}$ & 569 & 421 & 222 & $42.7 \pm 16.8$ & $21.2 \pm 0.4$ & 1.884 & 28 & 15 & 1.39 & 0.423 \\
\hline $1 d^{a}$ & 540 & 581 & 44 & $29.2 \pm 24.4$ & $21.6 \pm 0.6$ & 1.031 & 29 & 28 & 2.43 & 0.738 \\
\hline $2 b^{a}$ & 569 & 150 & 67 & $55.1 \pm 9.9$ & $24.0 \pm 0.8$ & 0.899 & 26 & 29 & 2.57 & 0.832 \\
\hline $1 c^{a}$ & 538 & 216 & 137 & $47.9 \pm 20.4$ & $26.0 \pm 0.6$ & 0.985 & 31 & 31 & 2.78 & 0.833 \\
\hline $1 b^{b}$ & 534 & 873 & 350 & $49.9 \pm 24.2$ & $29.4 \pm 0.5$ & 3.771 & 44 & 12 & 2.91 & 0.793 \\
\hline $2 c^{a}$ & 571 & 74 & 78 & $59.3 \pm 14.5$ & $40.1 \pm 5.7$ & 0.591 & 23 & 39 & 1.97 & 0.670 \\
\hline $1 e^{b}$ & 527 & 1179 & 456 & $82.6 \pm 15.1$ & $42.7 \pm 0.5$ & 11.450 & 44 & 4 & 2.63 & 0.719 \\
\hline $1 \mathrm{j}^{\mathrm{b}}$ & 532 & 1443 & 147 & $97.3 \pm 18.4$ & $59.7 \pm 0.8$ & 5.460 & 27 & 5 & 2.52 & 0.794 \\
\hline $1 a^{b}$ & 534 & 460 & 266 & $77.1 \pm 32.9$ & $61.4 \pm 10.2$ & 4.316 & 47 & 11 & 3.10 & 0.830 \\
\hline $1 \mathrm{i}^{\mathrm{b}}$ & 535 & 1344 & 218 & $83.1 \pm 28.4$ & $73.5 \pm 12.5$ & 6.335 & 30 & 5 & 2.60 & 0.790 \\
\hline $1 f^{b}$ & 538 & 285 & 192 & $132.3 \pm 35.7$ & $156.9 \pm 36.2$ & 0.672 & 19 & 28 & 1.37 & 0.505 \\
\hline
\end{tabular}




\section{RESULTS}

At the 2 study sites, 13 tubeworm aggregations ranging in size from 121 to 1635 tubeworms were collected (Table 1). The majority of the aggregations were dominated by Lamellibrachia luymesi, which comprised an average of $72.4 \%$ of the tubeworms. However, one of the aggregations was almost entirely composed of L. luymesi $(1 \mathrm{~d}, 93.0 \%)$ and one contained a slight majority of Seepiophila jonesi (2c, 51.3\%). Aggregation ages estimated by the population growth model ranged from 8 to $157 \mathrm{yr}$. The majority of aggregations were on the younger end of this range with 7 of the 13 having an estimated age under $30 \mathrm{yr}$ and only one estimated to be over 75 yr old (1f). Estimated age was consistent among model runs as evidenced by the low SD.

Sulfide concentration was generally higher in samples taken near the sediment surface, and there was a general trend of declining sulfide concentrations with aggregation age (Fig. 1). Average sulfide concentration $\left(\mathrm{p}<0.001, \mathrm{r}^{2}=0.147\right)$ and concentration at sediment height $\left(p=0.002, r^{2}=0.335\right)$ declined with aggregation age. However, regressions between age and sulfide concentration at the mid-aggregation level $(\mathrm{p}=$ $\left.0.329, r^{2}=0.0\right)$ or plume height $\left(p=0.100, r^{2}=0.071\right)$ were not significant.

The collections contained at least 90 species (see Appendix 1, available at www.int-res.com/articles/ suppl/m305p017_app.pdf), with individual aggregations containing between 14 and 47 species. The total number of species is likely higher as the taxonomic status of the hydroids, chitons, and lucinid bivalves collected in the study remain unresolved. The hydroids appear to consist of at least 4 species (Bergquist et al. 2003a). A total of 4 species of chitons have been identified from upper Louisiana slope samples, with Leptochiton pergranatus and L. alveolus tentatively identified from a subset of the individuals obtained in this study (J. Sigwart pers. comm.). The lucinids appear to be 3 different species including Lucinoma atlantis, an undescribed species Lucinoma, and a new genus and species of lucinid (J. Taylor pers. comm.). The vesicomyid bivalve appears to be very similar to Vesicomya cordata, but the small size of the juveniles collected here prevented conclusive determination of their taxonomic identity. Further analysis of additional specimens is required to resolve the taxonomy of these groups. The number of tubeworm-associated species was significantly correlated to habitat size (tube surface area, $r=0.665, p=0.013)$. The only species that were present in all collections were the polynoid polychaete Harmothoe sp. and the unidentified epifaunal sabellid polychaete. Other common species included the squat lobster Munidopsis sp. 1 (present in 12 of 13 collections), the shrimp Alvinocaris stactophila (12 of
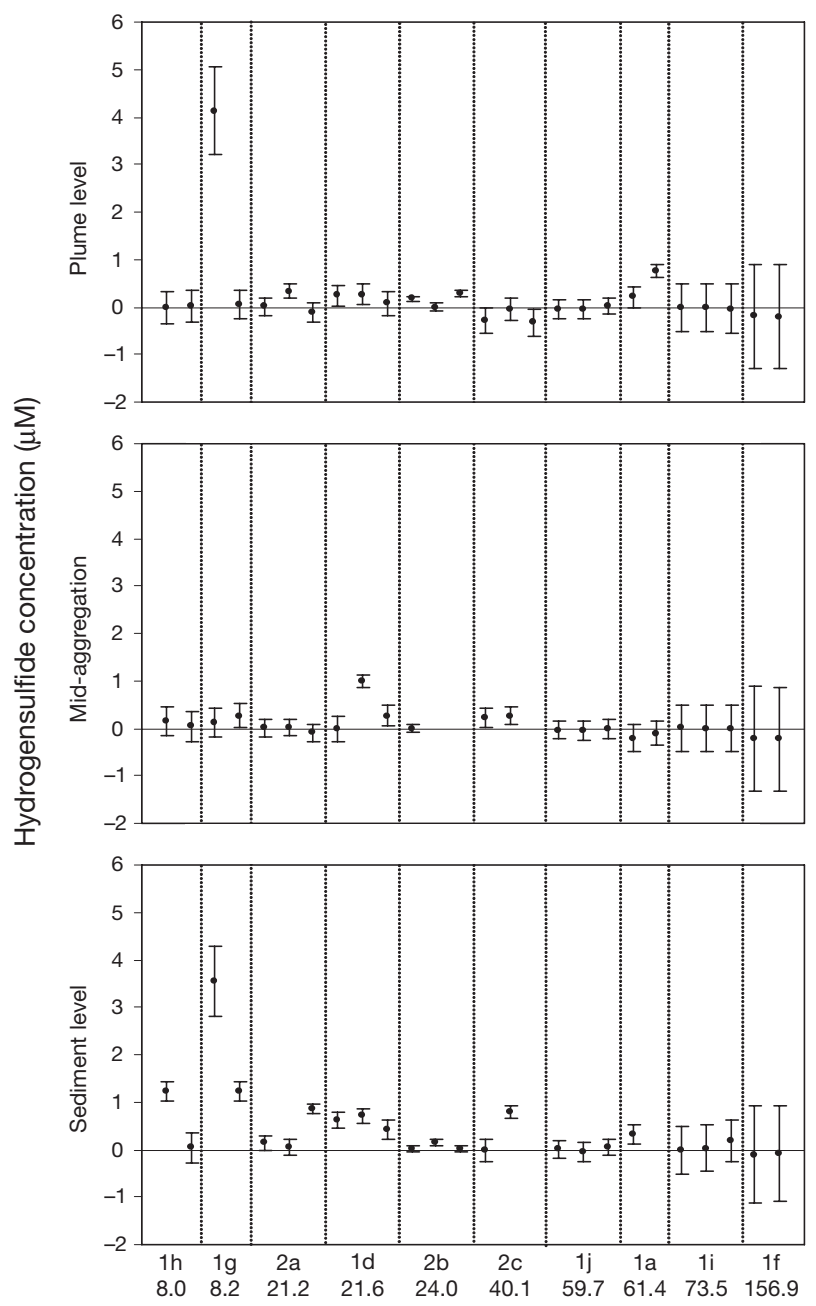

Aggregation (age)

Fig. 1. Sulfide concentration in tubeworm aggregations. Numbers in aggregation names refer to Site 1 (GC234) and Site 2 (GC232). Age of aggregation (log scale) as estimated by population growth model. Sulfide concentration was measured in water samples taken within tubeworm aggregations at plume level, mid-length of tubeworms (mid-aggregation), and near the sediment-water interface (sediment level). Individual samples are shown with error bars representing CIs from a regression of absorbance to concentration of known standards (see text for methodological details)

13), and the gastropod Provanna sculpta (10 of 13). Species with the highest densities (individuals $\mathrm{m}^{-2}$ tube surface area) were the gastropods Bathynerita naticoidea and P. sculpta, and A. stactophila. In terms of biomass ( $\mathrm{g} \mathrm{m}^{-2}$ tube surface area), the mussels Bathymodiolus childressi, B. naticoidea, and A. stactophila were the most dominant species.

In older tubeworm aggregations, associated fauna declined in terms of (log-transformed) biomass $\mathrm{m}^{-2}$ tubeworm surface area $(r=-0.641, p=0.046)$, density $(\mathrm{r}=-0.772, \mathrm{p}=0.002)$, and number of species $\mathrm{m}^{-2}$ (spe- 
cies density) ( $r=-0.640, p=0.019)$ (Table 1$)$. Biomass $\mathrm{m}^{-2}$ showed a strong positive correlation with average sulfide concentration within an aggregation $(r=0.920$, $p<0.001)$, as did density of associated fauna ( $r=0.756$, $p=0.011)$. Species density significantly increased with sulfide concentration $(r=0.787, p=0.007)$. The proportion of endemic species in the community was negatively correlated with aggregation age $(\mathrm{r}=-0.742, \mathrm{p}=$ 0.004 ) and increased in aggregations with higher sulfide concentrations $(r=0.849, p=0.002)$. Diversity was not linearly correlated to aggregation age $\left(H^{\prime}, \mathrm{p}=\right.$ $0.440 ; J^{\prime}, \mathrm{p}=0.562$ ) or average sulfide concentration $\left(H^{\prime}, \mathrm{p}=0.495 ; J^{\prime}, \mathrm{p}=0.680\right)$. Lowest diversity $\left(H^{\prime}\right.$ and $\left.J^{\prime}\right)$ communities were found in the 3 youngest aggregations $\left(H^{\prime}=1.39\right.$ to $1.60, J^{\prime}=0.423$ to 0.623$)$ and the oldest aggregation $\left(H^{\prime}=1.37, J^{\prime}=0.505\right)$ (Table 1$)$.

These patterns in community characteristics were accompanied by changes in trophic structure with aggregation age (Fig. 2). The proportion of biomass (not including tubeworms) in the primary producer $(\mathrm{r}=$ $-0.556, \mathrm{p}=0.049)$ and primary consumer $(\mathrm{r}=-0.571$, $p=0.041$ ) categories declined with age. Primary producer biomass (thiotrophic and methanotrophic bivalves) was higher in aggregations with higher average sulfide concentration $(r=0.897, p<0.001)$, but primary consumers showed no correlation to sulfide $(\mathrm{r}=$ $-0.054, p=0.882$ ). Together, primary producers and primary consumers made up ca. $90 \%$ of the nontubeworm biomass in the 2 youngest collections (ca. 8 yr). The second youngest collection (1g) had the highest measured sulfide concentrations and was the

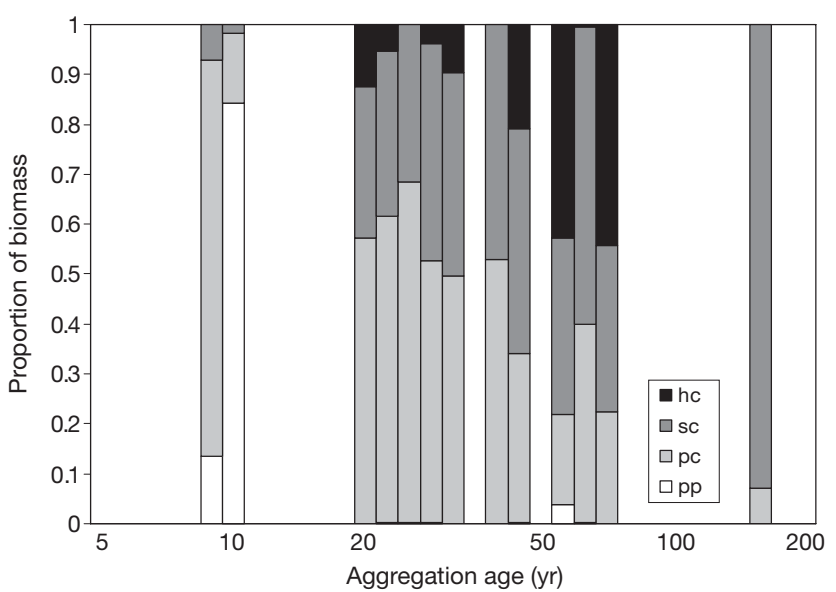

Fig. 2. Changes in trophic structure with aggregation age. Relative dominance (proportion of biomass) of 4 trophic levels indicated. (1) Primary producers ( $\mathrm{pp}$; include symbiotic bivalves but not tubeworms), (2) primary consumers ( $\mathrm{pc}$; grazing gastropods and crustaceans, deposit-, filter-, and suspension-feeding species), (3) secondary consumers (sc; predatory polychaetes, nemerteans, gastropods, and arthropods), (4) higher-order consumers (hc; fishes, seastars, and large crustaceans) only one to have significant associated-fauna biomass $(84 \%)$ in the form of the symbiotic mussel Bathymodiolus childressi. The next 6 aggregations, ranging from 21 to $40 \mathrm{yr}$ old, contained 50 to $68 \%$ of the associatedfauna biomass in the primary-consumer trophic level. Older aggregations ( $>40 \mathrm{yr}$ old) contained less than $40 \%$ primary-consumer biomass. The proportion of biomass of secondary consumers increased with age ( $\mathrm{r}$ $=0.875, \mathrm{p}<0.001$ ) and was lower in aggregations with high sulfide but was not significantly correlated with average sulfide concentration $(\mathrm{r}=-0.554, \mathrm{p}=0.097)$. Secondary consumers comprised $93 \%$ of the associated-fauna biomass in the oldest aggregation (157 yr, no detectable sulfide). Higher-level consumers showed no significant trend with age $(\mathrm{r}=0.375, \mathrm{p}=0.206)$ or sulfide concentration $(r=-0.445, p=0.198)$. Aggregations ranging in age from 21 to $74 \mathrm{yr}$ contained the occasional, often solitary, higher predator (fishes or decapod crustaceans).

Similarity among communities was assessed on a relative scale using multidimensional scaling (MDS) analysis (Fig. 3). In the subset of 10 aggregations for which all variables (depth, longitude, sulfide, age) could be tested, tubeworm aggregations that were similar in age (pairwise Euclidean distance in age) contained the most similar communities $(\mathrm{r}=0.523, \mathrm{p}<$ $0.001, \mathrm{n}=45$ ). When all 13 collections were entered into the analysis and sulfide removed as an environmental variable, similarity in age again provided the most highly significant predictor of community similarity $(\mathrm{r}=0.570, \mathrm{p}<0.001, \mathrm{n}=78)$. After age, average sulfide concentration $(\mathrm{r}=0.314, \mathrm{p}=0.036, \mathrm{n}=45)$, propor-

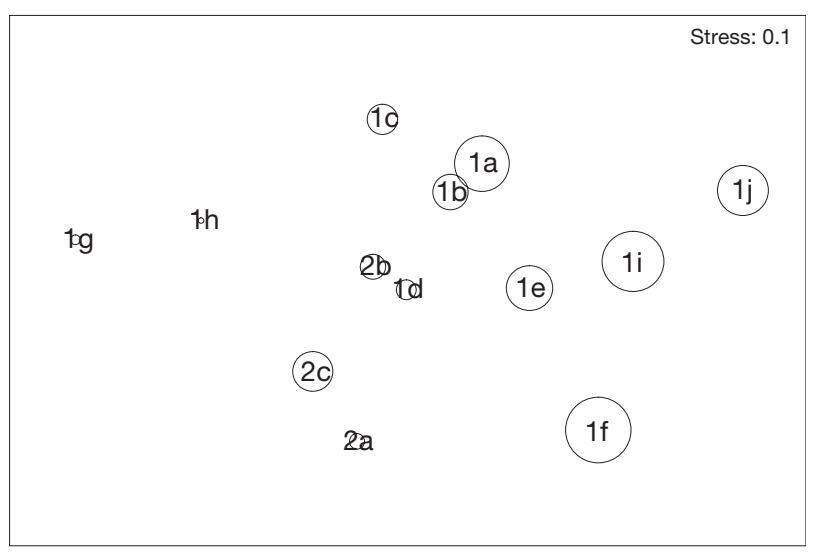

Fig. 3. Multidimensional scaling (MDS) plot of community similarity of tubeworm-associated fauna ( $>2 \mathrm{~mm}$ ). Placement of samples in 2 dimensions based on rank Bray-Curtis pairwise similarity in community structure. Samples that appear closer together have relatively greater pairwise similarity values, with the stress value of 0.1 indicating a reliable representation of community similarity in the ordination. Circle sizes = relative age of aggregation, with larger circles representing older aggregations 
tion of samples with detectable sulfide $(r=0.494, \mathrm{p}=$ $0.001, \mathrm{n}=45)$, and sulfide concentration at sediment level ( $\mathrm{r}=0.446, \mathrm{p}=0.002, \mathrm{n}=45$ ) exhibited the highest correlations to community similarity in the aggregations for which sulfide data were available.

The effect of distance between collections was negligible in the MDS analysis including all collections ( $\mathrm{r}=$ 0.030, $\mathrm{p}=0.796, \mathrm{n}=78$ ). Collections from the 2 study sites (GC234 and GC232) did not segregate in 2-dimensional space in the MDS plot (Fig. 3), and collections from 2 different sites (1d and $2 \mathrm{~b}$ ) had the second highest Bray-Curtis (BC) similarity (67.4). At local spatial scales there may be some effect of distance as there was a high degree of similarity between communities collected less than $2 \mathrm{~m}$ apart ( $1 \mathrm{a}$ and $1 \mathrm{~b}, \mathrm{BC}=78.3$ ). Depth was also not correlated to community similarity $(\mathrm{r}=0.005, \mathrm{p}=0.661, \mathrm{n}$ $=78$ ), showing that the minor changes in depth in this study $(44 \mathrm{~m})$ had little effect on community structure.

Trophic-level trends in community structure result from consistent patterns of co-occurrence at the species level. The most similar groupings of species involved endemic species that declined in abundance with aggregation age (Fig. 4), though the majority of correlations between species abundance and aggregation age or sulfide concentration were significant at the 0.05 level but not at the Bonferroni-corrected level $(p<0.002)$. One of the most highly supported interspecific associations was between the endemic shrimp Alvinocaris stactophila and the endemic galatheid Munidopsis sp. 1 whose distributions across aggregations shared a BC similarity of 76.2. A. stactophila abundance declined in older aggregations ( $\mathrm{r}=-0.825, \mathrm{p}=0.001$ ) and increased with average sulfide concentration $(\mathrm{r}=$ 0.644, $\mathrm{p}=0.044$ ), but Munidopsis sp. 1 showed no significant trend with age or sulfide. The deposit-feeding sipunculan Phascolosoma turnerae declined in abundance with aggregation age ( $\mathrm{r}=$ $-0.760, p=0.003$ ) and clustered with the predatory polychaete Glycera tesselata and the nemertean. The methanotrophic mussel Bathymodiolus childressi clustered with the endemic gastropods Provanna sculpta and Bathynerita naticoidea $(\mathrm{BC}=74.7)$. B. childressi $(\mathrm{r}=$ $-0.812, \mathrm{p}=0.001)$ P. sculpta $(\mathrm{r}=-0.755$, $\mathrm{p}=0.003)$, and $B$. naticoidea $(\mathrm{r}=-0.637, \mathrm{p}=0.019)$ all declined in abundance in older aggregations and increased in abundance with increased average sulfide concentration $(B$. childressi $\mathrm{r}=0.703, \mathrm{p}=0.023 ; P$. sculpta $\mathrm{r}=0.695, \mathrm{p}=0.026 ; B$. naticoidea $\mathrm{r}=0.713, \mathrm{p}=$ 0.021). The polynoid polychaetes Branchinotogluma sp. and Harmothoe sp. often co-occurred and showed a trend of decreased abundance in older aggregations (Branchinotogluma $\mathrm{r}=-0.733, \mathrm{p}=0.004$; Harmothoe $\mathrm{r}$ $=-0.660, \mathrm{p}=0.014)$ and increased abundance in more sulfidic habitats (Branchinotogluma $\mathrm{r}=0.671, \mathrm{p}=$ 0.034; Harmothoe $\mathrm{r}=0.669, \mathrm{p}=0.034)$. These polychaetes were distributed similarly to the gastropod

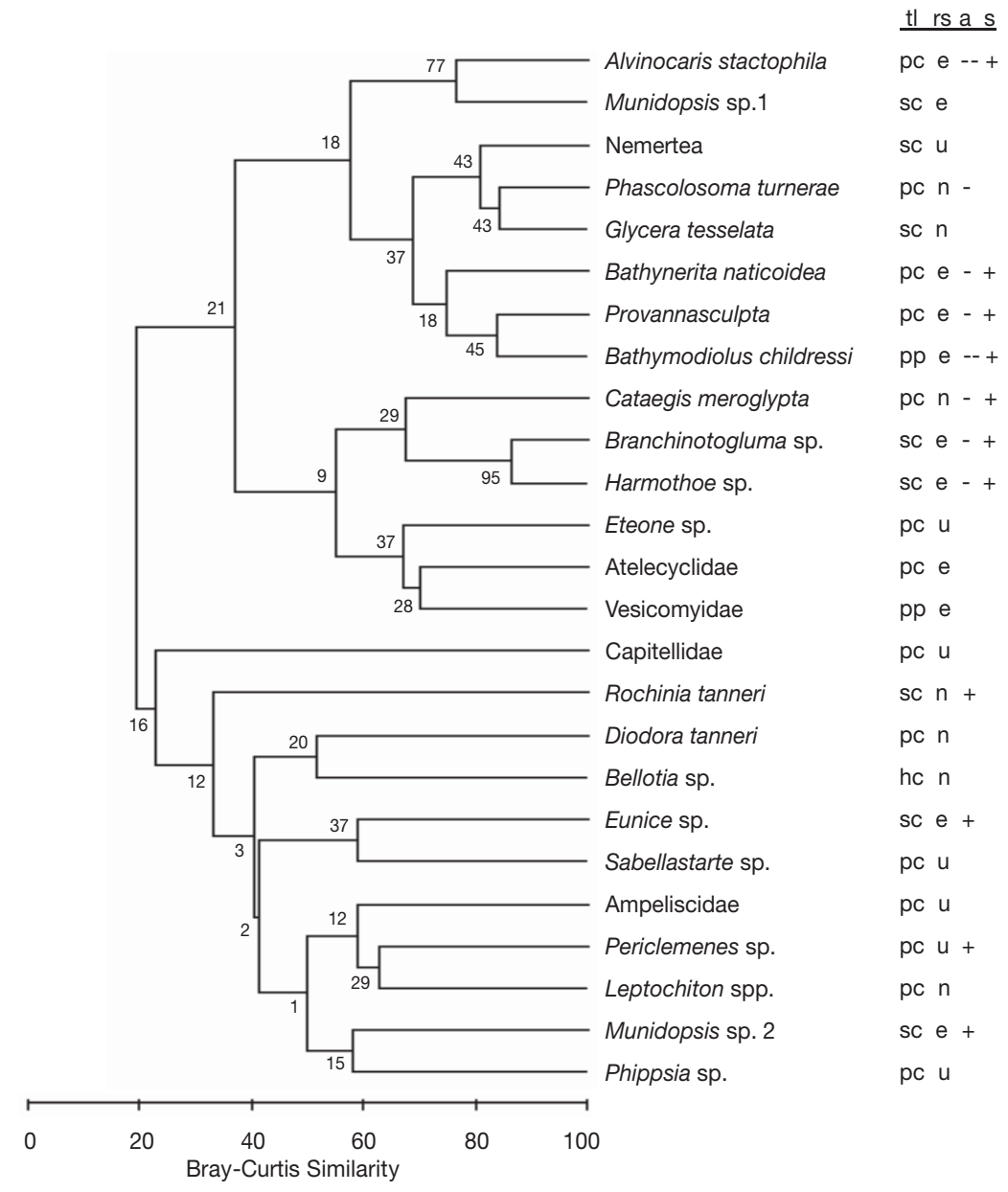

Fig. 4. Similarity in species distribution among aggregations. Cluster analysis (group average linkage) based on Bray-Curtis similarity of standardized density of species among aggregations. Numbers in figure refer to bootstrap value for each branch in cluster, with higher values indicating greater confidence in hierarchical cluster. Trophic levels (tl), assigned as in Fig. 2, are as follows: pp: primary producer, pc: primary consumer, sc: secondary consumer, hc: higher consumer. Residency status (rs) includes endemic species (e), non-endemic species (n), and species of unknown status $(\mathrm{u})$. Correlation of species distribution with aggregation age (a) and sulfide concentration (s) shown as positive (+) or negative (-) with one symbol representing a significant correlation at 0.05 confidence level and 2 symbols denoting a significant correlation at Bonferronicorrected confidence level $(p=0.002)$ 
Cataegis meroglypta $(\mathrm{BC}=67.2)$, which exhibited declining abundance in older aggregations $(\mathrm{r}=-0.660$, $\mathrm{p}=0.014$ ) and increasing abundance with sediment level sulfide $(\mathrm{r}=0.726, \mathrm{p}=0.017)$.

A number of species increased in abundance in older aggregations. The shrimp Periclimenes sp. $(\mathrm{r}=0.569$, $\mathrm{p}=0.042$ ) and the galatheid Munidopsis sp. 2 ( $\mathrm{r}=$ $0.637, \mathrm{p}=0.019$ ) were more abundant in older aggregations and shared similar distributions $(\mathrm{BC}=61.7)$. Other species with elevated abundance in older aggregations were the predatory or scavenging crustacean Rochinia tanneri ( $\mathrm{r}=0.619, \mathrm{p}=0.024)$ and the predatory polychaete Eunice sp. ( $\mathrm{r}=0.569, \mathrm{p}=0.042)$. The abundance of the remaining common species showed no correlation with aggregation age or sulfide levels and only clustered at low similarities and low bootstrap values with others.

\section{DISCUSSION}

Predictable successional processes are occurring within the tubeworm-associated communities sampled here at seep sites on the upper Louisiana slope. Associated-fauna density and biomass, proportion of endemic species, and proportion of biomass in the primaryconsumer trophic level all declined in older aggregations, supporting the model put forth by Bergquist et al. (2003a). We provide further evidence that changing levels of hydrogen sulfide explain these trends, a mechanism that has been repeatedly invoked but not empirically demonstrated for the communities associated with tubeworm aggregations at Gulf of Mexico seeps. Overall biomass and density of fauna increased with sulfide concentration, likely due to increased local primary productivity. In addition, the proportion of endemic species significantly declined in older aggregations that are exposed to lower sulfide concentration. There was also a strong correlation between the proportion of associatedfauna biomass in the primary-producer trophic level and sulfide concentration. Together, estimated aggregation age and sulfide concentration, most notably at the sediment level, explain most of the variability in the MDS pattern of similarity in community structure. These findings and previous laboratory and modeling studies suggest that Lamellibrachia luymesi can alter the biogeochemistry of upper Louisiana slope seeps and reduce sulfide levels in the water around their tubes (Julian et al. 1999, Freytag et al. 2001, Bergquist et al. 2003a, Cordes et al. 2003, 2005). These changes in water chemistry may promote colonization by non-endemic predatory species that could consume or outcompete endemic species. Thus, $L$. luymesi facilitates the progression of communities associated with its biogenic habitat toward later successional stages.

In the aggregations sampled here, the mussel with methanotrophic symbionts Bathymodiolus childressi and the commonly co-occurring gastropod Bathynerita naticoidea declined in abundance within the first $20 \mathrm{yr}$. Though methane concentrations were not measured in this study, previous studies demonstrated strong correlations between mussel distribution and growth and methane concentration (Cary et al. 1988, Nix et al. 1995, Smith et al. 2000). Growth of tubeworm aggregations may inhibit the persistence of $B$. childressi through occlusion or diversion of existing seepage conduits and drive succession toward the later tubeworm aggregation stages. While primary producer species still occasionally appear in older aggregations, these are more commonly burrowing bivalves with chemoautotrophic symbionts. By mining sulfide from within the interstices of shallow sediments (Fisher 1990), these autotrophs avoid the limitation of sulfide in the water column.

When aggregations reach 20 to 40 yr of age, epibenthic sulfide concentrations are lower than in young (<10 yr) aggregations, particularly at sediment level (Fig. 1). Hydrogen sulfide can have deleterious effects on an organism by binding to cytochrome-C oxidase and inhibiting aerobic respiration. Sulfide-tolerant species often possess specific mechanisms for sequestering or detoxifying sulfide (see review by Somero et al. 1989, and references therein). In addition to Bathymodiolus childressi and Bathynerita naticoidea, the species that appear to be most adversely affected by reduced epibenthic sulfide (and methane) concentrations are the endemic shrimp Alvinocaris stactophila, the endemic gastropod Provanna sculpta, the endemic polynoid polychaetes, the gastropod Cataegis meroglypta, and the deposit-feeding sipunculan Phascolosoma turnerae (Fig. 4). All of these species exhibited significant declines in abundance with aggregation age, and abundances of all but $P$. turnerae were positively correlated with the presence of sulfide. These endemic grazers and micropredators are presumably able to utilize the increased local productivity due to better tolerance to sulfide exposure than most nonendemic species. Although sulfide tolerance has been studied in a variety of animals, the mechanisms that allow these and many other endemic species from seeps and hydrothermal vents to occupy sulfide-rich habitats remain unknown and provide ample ground for future investigations.

Once sulfide levels decline, the tolerance of these species to sulfide would presumably cease to afford them a competitive advantage. The galatheid Munidopsis sp. 1 and the species it shared the most similar distribution with, the bresilid shrimp Alvinocaris stac- 
tophila, are likely competing with 2 other species, Munidopsis sp. 2 and the shrimp Periclimenes sp. Munidopsis sp. 1 and A. stactophila significantly decline in abundance over time, suggesting that in the absence of sulfide, Munidopsis sp. 2 and Periclimenes have the competitive advantage. It is possible that this is a general trend with Lamellibrachia luymesi facilitating the replacement of species with high sulfide tolerances by species with better resistance to predation or more efficient feeding strategies over time. Some species that occur more commonly in older aggregations inhabit the upper portions of aggregations away from the sediment surface and the source of sulfide. These include the mobile crab Rochinia tanneri and the polychaete Eunice sp., which forms tubes on the anterior portions of the vestimentiferan tubes.

The relative dominance of endemic primary consumers continues to decline until their biomass is exceeded by the biomass of secondary consumers in aggregations of 40 to $75 \mathrm{yr}$ of age that contain little or no sulfide. It is possible that the characteristics of these communities are influenced by the collection device since all older (and therefore large) aggregations were collected with the Bushmaster Sr. (Table 1). However, the only difference in the devices is their size (net volumes and open diameters). If there were differences in retention efficiency of the 2 Bushmaster devices or their recovery apparatus, it did not appear to influence the results since younger collections made with the Bushmaster Sr. device were similar to collections made with the Bushmaster Jr.

The 40 to $70 \mathrm{yr}$ time period coincides with previous estimates for the upper limit of the Lamellibrachia luymesi settlement period within a single aggregation (Bergquist et al. 2000, Cordes et al. 2003). Size frequencies of 6 of the 7 aggregations estimated to be less than 40 yr of age suggested active recruitment; only in $2 \mathrm{~b}$ did the absence of individuals in the smallest size class of vestimentiferans suggest that active recruitment was not occurring. The only aggregation over $40 \mathrm{yr}$ of age with tubeworm individuals in the smallest size class was the 61 yr old aggregation (1a). While micromolar levels of sulfide were detected among the tubes of this aggregation, no sulfide was detectable in the 3 other aggregations of comparable age or older. Since the presence of sulfide is a requirement for successful metamorphosis of tubeworm larvae (Tyler \& Young 1999), the previously reported recruitment estimates are consistent with the temporal trends in the community and sulfide data found here. By lowering epibenthic sulfide concentration, L. luymesi may inhibit additional tubeworm recruitment, thereby lessening intraspecific competition for limited sulfide resources.
The oldest aggregation sampled was considerably older than all others, and its size tested the limits of our sampling equipment. There was no sulfide detected within this aggregation, diversity was low, primary consumers were nearly absent, and nonendemic species dominated the community of associated fauna. At this point, in aggregations over $150 \mathrm{yr}$ old, the physical structure created by the tubeworms is bathed in ambient bottom water and is largely uninfluenced by seep fluids. It is unknown how long tubeworm aggregations in this final stage of succession may persist, as the upper limit of Lamellibrachia luymesi longevity is unknown. The paucity of community structure and growth data in older aggregations is mainly due to the constraints imposed on collecting large, old tubeworm aggregations by an $8 \mathrm{~m}$ long submersible with a $450 \mathrm{~kg}$ payload using extant collection equipment. At the 2 sites studied here, most single tubeworm aggregations were too large to sample, and clusters of aggregations forming uninterrupted fields covering hundreds of square meters were also present.

Upper trophic levels rarely dominate a community in terms of biomass. This is somewhat deceiving in the analysis presented here as the biomass of vestimentiferans, which accounts for over $99 \%$ of the total biomass in each collection, was not included in the trophic analysis. This omission follows the evidence from stable isotopic (MacAvoy et al. 2005) and palatability studies (Kicklighter et al. 2004) that indicate that there is little or no predation on adult tubeworms at these sites. High lifetime fecundity of tubeworms (Young et al. 1996) may provide a source of nutrition for some fauna, but tubeworm biomass does not appear to be a significant energetic input at the base of the food web. This is somewhat analogous to the role of trees in a forest where the vast majority of standing biomass is contained in the trunk and branches. In old tubeworm aggregations, nonendemic secondary consumers and scavengers may be taking advantage of the shelter afforded them by the relatively innocuous biogenic habitat to forage in surrounding mussel beds and younger tubeworm aggregations containing higher sulfide levels and prey abundance (Bergquist et al. 2003a, 2005). While individual aggregations function as isolated 'habitat islands' (Bergquist et al. 2003a) in that they progress through a predictable successional sequence, there is also a certain degree of interconnection via nonendemic foraging species such that the aggregations should be viewed in a metacommunity context (Wilson 1992).

Significant differences in community structure with sulfide concentration have been shown in a variety of other seep habitats. Three distinct community types 
are associated with different sulfide regimes overlying gas hydrates on the Cascadia convergent margin (Sahling et al. 2002). The composition of infaunal communities at northern California methane seeps is also directly related to interstitial sulfide concentrations (Levin et al. 2003). Flow rates of seeping fluids transporting hydrocarbons and sulfide to the sediment surface affect the chemosynthetic community structure around the periphery of mud volcanoes near the Barbados accretionary prism (Olu et al. 1997).

At hydrothermal vents, shifts in community structure have also been attributed to changes in habitat chemistry. On the Juan de Fuca ridge, vent communities progress through early successional stages in less than $1 \mathrm{yr}$, with a complete cycle of emergence and disappearance of tubeworm aggregations in less than $8 \mathrm{yr}$ (Tsurumi \& Tunnicliffe 2001). When new localized sources of vent fluid appear, migration of heterotrophic fauna may occur within minutes, and community-wide changes can occur within $1 \mathrm{~d}$ (Sarrazin et al. 1997). At East Pacific Rise hydrothermal vents, community succession has been demonstrated on temporal scales of months to years (Shank et al. 1998) and is correlated to changes in chemistry, although biotic interactions have a significant influence on the progression of successional stages (Micheli et al. 2002, Mullineaux et al. 2003). The longevity of seep tubeworms (Fisher et al. 1997, Bergquist et al. 2000) and the persistence of seep sites (Sassen et al. 1994, Aharon et al. 1997) in the Gulf of Mexico results in community succession on temporal scales measured in decades to centuries rather than months to years.

The physical structure created by Lamellibrachia luymesi harbors high-biomass communities at hydrocarbon seeps on the Gulf of Mexico continental slope. In addition to refugia, the complex structure of tubeworm tubes provides a substrate for endemic grazing species that can tolerate exposure to seep fluids in young aggregations and foraging grounds for nonendemic species in older aggregations where sulfide is absent. Where these communities overlap, the highest-diversity tubeworm-associated communities are found. By altering the habitat chemistry within aggregations, L. luymesi facilitates the colonization of nonendemic predatory species. This accelerates the progression toward later successional stages and increases the level of interaction between the seependemic and background Gulf of Mexico communities. Since L. luymesi is an extremely long-lived organism, these effects persist on temporal scales measured in centuries. The spatial and temporal scales on which the habitat created by upper Louisiana slope tubeworms persists ranks L. luymesi as one of the most significant foundation species in the deep sea as a whole.
Acknowledgements: We thank K. Shea, M. Arthur, P. Hudson, L. Levin, and 3 anonymous reviewers for their insightful comments on this manuscript. We acknowledge C. Jones for collecting some of the sulfide concentration data included in this study. J. Barsic, N. Iacchei, and B. Tiegs contributed to the enumeration and measurement of tubeworms and associated fauna. We thank A. Waren for his assistance with the identification of gastropods, S. Stohr for her assistance with the identification of the ophiuroids, J. Sigwart for her identification of chitons, and J. Taylor, A. Holmes, and G. Oliver for their assistance with lucinid taxonomy. This study would not have been possible without the contributions of the captain and crew of the RV Seward Johnson II and the pilots of the DSV Johnson Sea-Link. We also thank S. Arellano, D. Bergquist, R. Carney, S. Dattagupta, B. Govenar, A. Hilario, J. Jarnegren, M. McGinley, B. Pflugfelder, L. Podowski, K. Shea, G. Telesnicki, A. Van Gaest, and C. Young for their assistance and discussions at sea. This work was supported by NSF OCE0117050, the NOAA Ocean Exploration Program, and the NOAA National Undersea Research Program at the University of North Carolina, Wilmington. E. Cordes also received support from the NOAA Nancy Foster Scholarship program.

\section{LITERATURE CITED}

Aharon P, Fu B (2000) Microbial sulfate reduction rates and oxygen isotope fractionations at oil and gas seeps in deepwater Gulf of Mexico. Geochim Cosmochim Acta 62:233-246

Aharon P, Fu B (2003) Sulfur and Oxygen isotopes of coeval sulfate-sulfide in pore fluids of cold seep sediments with sharp redox gradients. Chem Geol 195:201-218

Aharon P, Schwarcz HP, Roberts HH (1997) Radiometric dating of submarine hydrocarbon seeps in the Gulf of Mexico. Geol Soc Am Bull 109:568-579

Bergquist DC, Williams FM, Fisher CR (2000) Longevity record for deep-sea invertebrate. Nature 403:499-500

Bergquist DC, Urcuyo IA, Fisher CR (2002) Establishment and persistence of seep vestimentiferan aggregations from the upper Louisiana slope of the Gulf of Mexico. Mar Ecol Prog Ser 241:89-98

Bergquist DC, Ward T, Cordes EE, McNelis T and 5 others (2003a) Community structure of vestimentiferan-generated habitat islands from upper Louisiana slope cold seeps. J Exp Mar Biol Ecol 289:197-222

Bergquist DC, Andras JP, McNelis T, Howlett S, van Horn MJ, Fisher CR (2003b) Succession in Gulf of Mexico cold seep communities: the importance of spatial variability. PSZN I: Mar Ecol 24:31-44

Bergquist DC, Fleckenstein C, Knisel J, Begley B, MacDonald IR, Fisher CR (2005) Variations in seep mussel bed communities along physical and chemical environmental gradients. Mar Ecol Prog Ser 293:99-108

Bertness MD, Leonard GH (1997) The role of positive interactions in communities: lessons from intertidal habitats. Ecology 78:1976-1989

Boetius A, Ravenschlag K, Schubert CJ, Rickert D and 6 others (2000) A marine microbial consortium apparently mediating anaerobic oxidation of methane. Nature 407: $623-626$

Brooks JM, Kennicutt MC, Fisher CR, Macko SA, Cole K, Childress JJ, Bidigare RR, Vetter RD (1987) Deep-sea hydrocarbon seep communities: Evidence for energy and nutritional carbon sources. Science 238:1138-1142

Bruno JF, Stachowicz JJ, Bertness MD (2003) Inclusion of facilitation into ecological theory. Trends Ecol Evol 18: $119-125$ 
Carney RS (1994) Consideration of the oasis analogy for chemosynthetic communities at Gulf of Mexico hydrocarbon vents. Geol Mar Lett 14:149-159

Cary SC, Fisher CR, Felbeck H (1988) Mussel growth supported by methane as sole carbon and energy source. Science 240:78-80

Clarke KR, Warwick RM (2001) Change in marine communities: an approach to statistical analysis. Primer-E, Plymouth

Connell JH (1978) Diversity in tropical rain forests and coral reefs. Science 199:1302-1310

Cordes EE, Bergquist DC, Shea K, Fisher CR (2003) Hydrogen sulphide demand of long-lived vestimentiferan tube worm aggregations modifies the chemical environment at hydrocarbon seeps. Ecol Lett 6:212-219

Cordes EE, Arthur MA, Shea K, Arvidson RS, Fisher CR (2005) Modeling the mutualistic interactions between tubeworms and microbial consortia. PLoS: Biol 3:497-506

Fauchald K, Jumars PA (1979) The diet of worms: a study of polychaete feeding guilds. Oceanogr Mar Biol Annu Rev 17:193-284

Fisher CR (1990) Chemoautotrophic and methanotrophic symbioses in marine invertebrates. Rev Aquat Sci 2:399-436

Fisher CR, Urcuyo IA, Simkins MA, Nix E (1997) Life in the slow lane: growth and longevity of cold-seep vestimentiferans. Mar Ecol 18:83-94

Formolo MJ, Lyons TW, Zhang C, Kelley C, Sassen R, Horita J, Cole DR (2004) Quantifying carbon sources in the formation of authigenic carbonates at gas hydrate sites in the Gulf of Mexico. Chem Geol 205:253-264

Freytag JK, Girguis PR, Bergquist DC, Andras JP, Childress JJ, Fisher CR (2001) A paradox resolved: sulphide acquisition by roots of seep tubeworms sustains net chemoautotrophy. Proc Natl Acad Sci USA 98:13408-13413

Hacker SD, Gaines SD (1997) Some implications of direct positive interactions for community species diversity. Ecology 78:1990-2003

Harris LG, Ebeling AW, Laur DR, Rowley RJ (1984) Community recovery after storm damage: a case of facilitation in primary succession. Science 224:1336-1338

Higashi M (1993) An extension of niche theory for complex interactions. In: Kawanabe H, Cohen JE, Iwasaki K (eds) Mutualism and community organization. Oxford University Press, Oxford, UK

Joye SB, Boetius A, Orcutt BN, Montoya JP, Schulz HN, Erickson MJ, Lugo SK (2004) The anaerobic oxidation of methane and sulfate reduction in sediments from Gulf of Mexico cold seeps. Chem Geol 205:219-238

Julian D, Gaill F, Wood E, Arp AJ, Fisher CR (1999) Roots as a site of hydrogen sulphide uptake in the hydrocarbon seep vestimentiferan Lamellibrachia sp. J Exp Biol 202:2245-2257

Kicklighter CE, Fisher CR, Hay ME (2004) Chemical defense of hydrothermal vent and hydrocarbon seep organisms: a preliminary assessment using shallow-water consumers. Mar Ecol Prog Ser 275:11-19

Levin LA, Ziebis W, Mendoza GF, Growney VA and 5 others (2003) Spatial heterogeneity of macrofauna at northern California methane seeps: influence of sulfide concentration and fluid flow. Mar Ecol Prog Ser 256:123-139

Luff R, Wallmann K, Aloisi G (2004) Numerical modelling of carbonate crust formation at cold vent sites: significance for fluid and methane budgets and chemosynthetic biological communities. Earth Planet Sci Lett 221:337-353

MacAvoy SE, Carney RS, Macko SA, Fisher C (2002) The use of chemosynthetically derived nutrients by large, mobile, benthic predators in the Gulf of Mexico. Mar Ecol Prog Ser 225:65-78
MacAvoy SE , Fisher CR, Carney RS, Macko SA (2005) Nutritional associations among fauna at hydrocarbon seep communities in the Gulf of Mexico. Mar Ecol Prog Ser 292: $51-60$

MacDonald IR, Guinasso NL, Reilly JF, Brooks JM, Callender WR, Gabrielle SG (1990) Gulf of Mexico seep communities: VI. Patterns in community structure and habitat. GeoMar Lett 10:244-252

Micheli F, Peterson CH, Mullineaux LS, Fisher CR, Mills SW, Sancho G, Johnson GA, Lenihan HS (2002) Predation structures communities at deep-sea hydrothermal vents. Ecol Monogr 73:365-382

Mullineaux LS, Peterson CH, Micheli F, Mills SW (2003) Successional mechanism varies along a gradient in hydrothermal fluid flux at deep-sea vents. Ecol Monogr 73:523-542

Naiman RJ, Melillo JM, Hobbie JE (1986) Ecosystem alteration of boreal forest streams by beaver (Castor canadensis). Ecology 67:1254-1269

Nix E, Fisher CR, Scott KM, Vodenichar J (1995) Physiological ecology of a mussel with methanotrophic symbionts at three hydrocarbon seep sites in the Gulf of Mexico. Mar Biol 122:605-617

Odum EP (1969) The strategy of ecosystem development. Science 164:262-270

Olu K, Lance S, Sibuet M, Henry P, Fiala-Medioni A, Dinet A (1997) Cold seep communities as indicators of fluid expression patterns through mud volcanoes seaward of the Barbados accretionary prism. Deep-Sea Res 44: 811-841

Ricciardi A, Bourget E (1998) Weight to weight conversion factors for marine benthic invertebrates. Mar Ecol Prog Ser 163:245-251

Sager WW, MacDonald IR, Hou R (2003) Geophysical signatures of mud mounds at hydrocarbon seeps on the Louisiana continental slope, northern Gulf of Mexico. Mar Geol 198:97-132

Sahling H, Rickert D, Lee RW, Linke P, Suess E (2002) Macrofaunal community structure and sulfide flux at gas hydrate deposits from the Cascadia convergent margin, NE Pacific. Mar Ecol Prog Ser 231:121-138

Sarrazin J, Robigou V, Juniper SK, Delaney JR (1997) Biological and geological dynamics over four years on a hightemperature sulfide structure at the Juan de Fuca Ridge hydrothermal observatory. Mar Ecol Prog Ser 153:5-24

Sassen R, MacDonald IR, Requejo AG, Guinasso NL, Kennicutt MC (1994) Organic geochemistry of sediments from chemosynthetic communities, Gulf of Mexico slope. GeolMar Lett 14:110-119

Shank TM, Fornari DJ, Von Damm KL, Lilley MD, Haymon RM, Lutz RA (1998) Temporal and spatial patterns of biological community development at nascent deep-sea hydrothermal vents ( $9^{\circ} 50^{\prime} \mathrm{N}$ East Pacific Rise). Deep-Sea Res II 45:465-515

Singh R, Blattler WA, Collinson AR (1993) An amplified assay for thiols based on reactivation of papain. Anal Biochem 213:49-56

Smith EB, Scott KM, Nix ER, Korte C, Fisher CR (2000) Growth and condition of seep mussels (Bathymodiolus childressi) at a Gulf of Mexico brine pool. Ecology 81:2392-2403

Sokal RR, Rohlf FJ (1995) Biometry: the principles and practice of statistics in biological research, 3rd edn. Freeman, New York

Somero GN, Childress JJ, Anderson AE (1989) Transport, metabolism, and detoxification of hydrogen sulfide in animals from sulfide-rich marine environments. Rev Aquat Sci 1:591-614

Stachowicz JJ (2001) The other side of the coin: positive 
effects of algal chemicals on animals. J Phycol 37:46-56

Tsurumi M, Tunnicliffe V (2001) Characteristics of a hydrothermal vent assemblage on a volcanically active segment of Juan de Fuca Ridge, northeast Pacific. Can J Fish Aquat Sci 58:530-542

Tyler PA, Young CM (1999) Reproduction and dispersal at vents and cold seeps. J Mar Biol Assoc UK 79:193-208

Waren A, Bouchet P (2001) Gastropoda and Monoplacophora

Editorial responsibility: Lisa Levin (Contributing Editor), La Jolla, California, USA from hydrothermal vents and seeps: new taxa and records. Veliger 44:116-231

Wilson DS (1992) Complex interactions in metacommunities with implications for biodiversity and higher levels of selection. Ecology 73:1984-2000

Young CM, Vazquez E, Metaxas A, Tyler P (1996) Embryology of vestimentiferan tube worms from deep-sea methane/sulfide seeps. Nature 381:514-516

Submitted: January 6, 2005; Accepted: July 16, 2005 Proofs received from author(s): November 22, 2005 